\title{
The message or the bottle? Community, associationism and adult learning as "part of the process of social change"
}

Raymond Williams argued that the "the impulse to adult education" was never solely focused on "remedying deficit, making up for inadequate educational resources in the wider society" (Williams, 1983, in Mcllroy and Westwood (Eds), 1993, p. 257). Nor was it primarily a response to "meeting new needs of the society". This chapter argues, as Williams did, that adult education has to be more than "the bottle with the message in it, bobbing on the tides and waves of history" (ibid, p. 255), springing urgently, instead, from the "the desire to make learning part of the process of social change itself (ibid, p. 257).

Williams' assertion suggests that Adult Education's political purpose comes through the lens of community and associationism and their contribution to an 'ethic of service' and to social justice. Concepts such as 'social mobility' and 'aspiration' are politically freighted ideas which mask real knowledge dispossession and social precarity. This chapter explores the important role adult education can play in 'left behind' communities in the grip of decline, focusing on the role of residential colleges and also non-formal, family and community learning in engaging at community level with those who have no overt 'voice' in the political system. Finally, the chapter explores the role of adult education in consciousness raising and in the construction of 'resources for a journey of hope', examining how awareness of community history and labour struggles have provided continuity and resilience in times of escalating turbulence.

\section{Historical Context}

Class and education have been at the centre of political and intellectual struggles in Britain for at least the last century. In 1958, Stuart Hall called out the great inequities in British society, highlighting the difference between its tone and manner, the use of "the language of equality" and "popular democracy", whilst an elite controlled access to real knowledge and power:

Surely there has never been a greater cleavage between the tone of our society, its manner and forms, and the gross realities. What happens to a society, rigidly class bound, which uses continually the language of equality? What happens to an oligarchy which conceals itself behind the rhetoric of the popular democracy? What happens when larger numbers are trained each year for responsibility and participation, but where the sources of power and decision grow everyday more remote? All our energies are expended in creating and 
consuming a culture whose sole purpose is to cover up the realities of our social life (Hall, 1958, p.1).

Hall's commentary is remarkably prescient today, particularly his suggestion that control by the oligarchy masks the "gross realities" of our cultural and social life which become part of the natural order, seen through the distorting lens of a "debased political language" which uses democracy as a smoke screen (Hall, 1958, p.1). His use of the word "train" in relation to education is also significant and he emphasised the futility of such training when the sources of power retreat, chimera-like, further away from the world of the majority of us who are "creating and consuming" this same culture and are skewered by a rigid class structure. If the "realities of our social life" are so obscured, the prospect of a genuine knowledge democracy, as part of our shared associational life in which we collectively re-shape, re-think and re-frame what society should look like, becomes remote. In contemporary Austerity Britain, in which class domination is achieved through a system of "accumulation by dispossession" (Sanchez, 2018, p.302), it is timely that we seek to reconnect with Hall's words.

\section{Class, Knowledge dispossession and austerity}

Austerity is a class project that disproportionately targets and affects working-class households and communities and, in doing so, protects concentrations of elite wealth and power (Cooper and Whyte, Eds, 2017, p.11).

The reality for many people in contemporary Britain is that we are living in increasingly precarious circumstances which are decoupled from an optimistic future, and do not provide spaces in which the complexity of modern economic life can be debated. Andrew Sanchez has argued that "conceptual models of the precariat fail to grasp class as a dynamic historical object that intersects with experiences of struggle, decline, hope, and fatalism" (Sanchez, 2018, p.303). For Sanchez, our concepts of ourselves as belonging to a particular class - not just a group of individuals living precariously - with a shared history, memories and instances of managing previous struggles, is allimportant in countering a sense of despair and impotence, particularly in the communities hardest hit by the exigencies of the past three decades (and more), in the former coalfields and manufacturing bases.

Language is profoundly political. The British media has continued its steady and persistent drip feed of anti-immigration commentary, its rhetoric of 'the deserving and undeserving poor', 'chavs', 'scroungers and spongers', amplifying the demonization of those in precarious employment, living on the margins, and has led to deep rifts in British society, as exemplified by the Brexit vote. Statistics from the Joseph Rowntree Foundation (Annual Report, 2015) show that the proportion of people 
living in households with an income below the Minimum Income Standard (MIS) increased by nearly a third between 2008/09 and 2012/13. More recently, families have seen the greatest increase in poverty, with at least 8.1 million parents and children now living at an income level below that necessary to cover a minimum household budget, up by more than a third from 5.9 million in 2008/09. The Brexit Leave vote has been ascribed in large part to people from the Traditional Working Class, from the old manufacturing bases, registering a vote of anger against the current order. This is an order in which social mobility has not improved but has worsened over the last 30 years. Precarious work and zero hours' contracts - the 'gig economy' - have dominated as modes of employment, with none of the hard-won rights and responsibilities of the labour movement in place. The Chartered Institute for Professional Development has estimated that "there are 1.3 million Britons employed in the gig economy, while the TUC says that one-in-ten British workers are in 'precarious work'"'(Wired, 2017). Many communities in the former coalfield areas have seen no resurgence of dignified work and some places act as little more than dormer towns supplying cheap labour to the bigger cities. The sense of being part of a settled community based on collectivised work, such as mining, has been eroded and transience is becoming routine due to market forces; as people have to move away for work, social networks are being eroded. Such communities are demonized, 'left behind', perceived as second class and as being in deficit - economically, culturally and intellectually.

Class, as an expression of our standing in the social hierarchy and, a perhaps more fluid concept, our social-economic status, has long been a central preoccupation in British life, though not always overtly. Its interconnection with conceptions of democracy, or a democratic society, are critical here, as are specific connections with education. Mass education was the result of the principle of education for all children expressed in the 1870 Elementary Education Act and the later 1944 Education Act, which created an education system which was free for all children and raised the school leaving age to 15. From the late nineteenth and early twentieth century, fear of the newly educated and recently enfranchised members of the working classes were writ large amongst a wide range of writers and public intellectuals. Virginia Woolf, for example, is illustrative of the not uncommon fear amongst her own class (upper-middle, educated) that mass education was endangering the role of the educated middle classes and the intelligentsia as the bastion of culture. Her anxiety was that democracy would distort, dilute and trivialise culture and that art, as common property, would cease to be sublime and would descend into banality. She felt that the working classes were both ill-equipped and too unstable emotionally, psychologically and intellectually for the challenge of preserving and promoting the best of culture, seeing this class as "A vast, featureless, almost shapeless jelly of human stuff - occasionally 
this way or that as some instinct of hate, revenge, or admiration bubbles up beneath it" (Woolf, quoted in McNeilie, 1988, p.3).

These issues were very much alive between the wars and in the post-Second World War period. In The Road to Wigan Pier (1937), George Orwell railed against the absurdity of the finer gradations of the social hierarchy, as "the shadowy caste-system of class; rather like a jerrybuilt modern bungalow haunted by medieval ghosts" (Orwell, 1937, p.113). He was also very precise in his description of his own family as "lower-upper-middle class" (Orwell, 1937, ibid), noting, sardonically, that this was the upper middle class without money. For him, class was not about money but, much more subtly, about conceptions of taste, culture and "decency". He argued that the "unthinking person of gentle birth" (as above, p.123) needs only a spark to rouse his "dormant class-prejudice":

In his eyes the workers are not a submerged race of slaves, they are a sinister flood creeping upwards to engulf himself and his friends and his family and to sweep all culture and all decency out of existence. Hence that queer watchful anxiety lest the working class shall grow too prosperous (Orwell, 1937, p. 123).

Richard Hoggart summarised the enduring power of the English preoccupation with class in his 1989 introduction to The Road to Wigan Pier. He stated that: "Class distinctions do not die; they merely learn new ways of expressing themselves. Orwell's stance in this matter is completely up to date. Each decade we shiftily declare we have buried class; each decade the coffin stays empty" (Hoggart, 1989, p. vii).

Class fell out of fashion as a critical means of examining identity from the 1980s, replaced in large part by individual identity issues, with an emphasis on race, gender, sexuality and disability (Savage, 2007). In 1997 the then new Prime Minister Tony Blair pledged that social class was no longer a relevant concept and that our collective aspiration should be towards a classless society in which no one social class should prevail over another. His means of achieving 'classlessness' was through education, conceived as a profoundly liberating force. Continuing with Margaret Thatcher's embrace of free market economics, Blair argued that we should all become entrepreneurs, self-made people living within a freelance culture in which the individual is paramount and in which education should support our capacity to work by offering us employability skills, making us flexible and responsive to constant change and uncertainty in an increasingly globalised economy. Like James Callaghan in the 1970s, the concept of education Blair outlined focused not just on academic pursuits and the massification of Higher Education but on creating a workforce equipped with the appropriate skills for the modern age. As Callaghan expressed it in his famous speech at Ruskin College in Oxford in 1976:

There is no virtue in producing socially well-adjusted members of society who are unemployed because they do not have the skills. Nor at the other extreme must they be technically efficient 
robots. Both of the basic purposes of education require the same essential tools. These are basic literacy, basic numeracy, the understanding of how to live and work together, respect for others, respect for the individual (Callaghan, 1976).

Neoliberalism proposes that human advancement is best achieved by "liberating individual entrepreneurial freedoms and skills within an institutional framework characterized by strong private property rights, free markets, and free trade" (Harvey, 2007, p.2, quoted in Holford, 2016, p.544). Wider concepts of public education for the creation of "well-adjusted" human beings and citizens have tended to be reserved for the world of Higher Education. The primary pressure, and the funding impetus, over the last three decades and more has been to train people for roles and jobs. The emphasis on the trained individual is important here as the individual becomes the primary focus, rather than the community. 'Community' is many things to many people but it implies a sense of association - a commonality of purpose, interest or place; a network, a collective. The ideology of neoliberalism does not encourage debates about culture, community, class and history - it seeks to erase our collective memory, preferring a state of eternal present in which the "realities of our social life" are not subject to scrutiny. The self-made individual must run ever faster to stay in place, with the spectre of precarity looming at every turn. Tacit, community-based, knowledge, which is intuitive, sometimes hard to articulate and often acquired through lengthy practical experience, is outside of this frame of reference.

Recent research by the Institute for Voluntary Action Research (IVAR) into poor communities and how they are faring in the face of austerity shows fractures and rifts, increasing social isolation and mental ill health, greater dependence on food banks and a lack of community spaces in which to come together. It is what interview respondents have described as 'all-encompassing, post-industrial, deeply rooted social poverty' which consumes energy and time and militates against community engagement:

"The pressures of poverty militate against people's ability to engage with their communities - people's energies are consumed in the struggle to survive and they are frequently holding down several jobs and/or working in the insecure 'gig economy'"' (IVAR, 2018, p.3)

Over the past two decades, Mike Savage has done much to revive the sociology of class and, in particular, an emphasis on class consciousness in the sense of shared understanding of lifestyles, cultural interests, social networks and political orientations, as Sanchez has also described it. Savage writes in the Introduction to Social Class in the $21^{\text {st }}$ Century,

We like to think of ourselves as living in a democratic society where individuals are supposed to have equal rights. Yet we also know that people's economic fortunes can be strikingly different. Symbolically, class is a lightning conductor for the anxieties this discrepancy between economic realities and our beliefs provokes (Savage, 2016, p.7). 
He calls into question concepts of equality and the economic realities beneath them. The BBC's Great British Class Survey of 2011, with its on-line Class Calculator, prompted enormous public interest, creating the largest survey of social class ever undertaken in Britain. The Class Survey delineated several new groups and some existing, but the Elite and the Established Middle Class remained resolutely at the top and inter-generational changes remained small. Savage and his team took two years to analyse the data and, in 2016, published Social Class in the $21^{\text {st }}$ Century. Savage argued that class has become newly important again in the first two decades of the twenty first century, due to rising social and economic inequality and particularly income disparity, which, despite Blair's focus on social mobility and meritocracy have worsened. In Savage's view "social class is now a very powerful force in the popular imagination" (Savage, 2016, p.6). There is every reason for this when educational statistics are considered in terms of class.

\section{Class and Education - the myth of social mobility?}

The links between individual and parental income are still stronger in the UK than in any other Organisation for Economic Co-operation and Development (OECD) country and British schools are more socially segregated than in any other country. Added to this, the UK is one of the lowest performing countries for income mobility across the OECD. This issue came to the forefront of research and news in early 2018. Family poverty measures, such as eligibility for free school meals, remain a strong predictor of the kind of education young people access (or do not). Education is clearly not equally available or equally valued. This is particularly true for fee-paying independent schools and also for grammar schools, which remain the 'gold standard' for secondary schooling for many purveyors of the mantra of meritocracy. However, a recent study by the Gorard and Siddiqui (2018) shows that "grammar schools in England take only a tiny proportion of pupils who are or have ever been eligible for free school meals (two per cent as opposed to 14 per cent nationally) and those they do take have been eligible for fewer years. Their concern is that this equates to a form of segregation on the grounds If class - "Segregation, whether racially or by religion or social class, may have alarming and dangerous consequences for the school system and for society more widely in the longer term" (Gorard and Siddiqui, 2018, p.5).

This inequity extends into Higher Education. Despite growing numbers of people participating in Higher Education, which reached 49\% in 2015/16 (Higher Education Initial Participation Rate (HEIPR)) ${ }^{1}$,

\footnotetext{
${ }^{1}$ The HEIPR continues to increase, reaching 49\% in 2015/16 up from 42\% in 2006/07, from Department for Education Participation Rates In Higher Education: Academic Years 2006/2007 - 2015/2016 (Provisional), SFR47/2017, 28th September 2017
} 
young people from lower socioeconomic backgrounds are not attending the elite Russell Group universities. According to a Sutton Trust report from 2017:

there remain barriers to elite higher education....There has been no trend of improvement in the gap in Russell Group attendance by socioeconomic status. The gap is even starker for Oxbridge attendance; state school students eligible for free school meals (FSM) are 55 times less likely to attend Oxford or Cambridge (Sutton Trust, 2017).

According to a recent article in The Times (March 2018) Oxford University takes 2.8 percent of students from the "poorest households", which is similar to Cambridge ${ }^{2}$. On average people from lower socioeconomic backgrounds make up 11.1 percent of the overall student population, with a disproportionate number attending non-Russell group universities such as Sunderland University (which ranks $102^{\text {nd }}$ in one UK university ranking) and Teesside University (which ranks 101st). The University of Hull tops the current equality of student intake poll by the Higher Education Policy Institute (HEPI), followed by the University of Derby. Students from lower socioeconomic backgrounds are far less likely to attend university and students from the poorest households (using FSM data) are 55 times less likely than independent school students to attend Oxford or Cambridge (Sutton Trust, 2010). It would seem that the level of education completed, as well as the type of school and university attended, remain huge determinants of social mobility in Britain. Large educational gaps remain and entrenched privilege continues in higher education.

Social mobility, according to The Sutton Trust - an educational charity - is foregrounded in the ability to break the link between "an individual's parental background and their opportunities to reach their full potential in terms of income and occupation. It is about better opportunities for each generation and making access to these opportunities fairer, regardless of background" (Sutton Trust, 2017). Diane Reay, by contrast, has argued that "social mobility is a red herring. Currently we don't have it - or very little of it....And the focus on social mobility neglects the fact that given the current high levels of inequality, social mobility is primarily about recycling inequality rather that tackling it" (Reay, 2012, p.5).

Reay's perspective would seem to be borne out by further research from The Sutton Trust which highlights that students from wealthier backgrounds are often advantaged in applying to Oxbridge by having greater access to information through their schools and family and social networks (Sutton Trust, 2016). Pierre Bourdieu developed a sociology of culture to grapple with these very issues. His theory - largely focused on class issues - emphasised the concept of 'capital' (or power) and social

\footnotetext{
${ }^{2}$ University of Cambridge is first in the 2018 UK rankings and University of Oxford is second.
} 
reproduction, and sought to unpick how dominant groups in society claim a natural legitimacy for their readings of culture. He explodes the sanctity of "economic disinterestedness" postulating, instead, that the elite in society promulgate the notion that economic capital is not bound up with social capital, which Bourdieu describes as the "social obligations" (Bourdieu, 1986, p.241) which bind society. He argued that these very social connections or networks are "convertible, in certain conditions, into economic capital and may be institutionalized in the forms of a title of nobility" (ibid, 1986, p.241). Bourdieu argued that cultural capital, like social capital, is convertible "into economic capital and may be institutionalized in the forms of educational qualifications" (Bourdieu, 1986, p.241). It can serve as a form of protection for the interests of those in power, ensuring that the educational system replicates "the reproduction of the social structure by sanctioning the hereditary transmission of cultural capital" (ibid, p.241). This theorisation provides a very useful framework for understanding the structural aspects of learning and how they become encoded in human culture and within our internal mental and emotional frameworks, or habitus, by a set of acquired sensibilities, schemata, tastes and dispositions.

In 'A Winning Personality' (2016) De Vries and Renfrow draw a direct correlation between personality and background and how this impacts on future earnings and social mobility. Non-cognitive skills such as confidence and personal presentation - play a critical role in standing out in the fiercely competitive world of work where "'essential life skills" are likely to be a key differentiator". They argue that "access to education and job opportunities is an ongoing issue with continued evidence of opportunity 'hoarding' through networks, information asymmetries, and social bias. Even when less well-off students attend the same university and study the same subject as their wealthier peers they earn over 10\% less per year" (De Vries and Renfrow, 2016). Choice in education is valorised but remains unequal in terms of access and distribution at both structural and psychological levels:

It is not just the neoliberal rhetoric around diversity that has worked to bury social class as a crucial axis of educational inequality whilst sanctioning an increasingly divisive and segregated system, the current discursive and policy status quo is one that valorizes choice whilst rarely recognizing that choices come with resources that remain very unequally distributed (Reay, 2012, p.6).

Raymond Williams identified the cultural hegemony implicit in elite education systems as leading to "a very restricted and privileged and stagnant view of the world" (Williams, 1983, p.255). We can add to this restricted picture a lack of professional representation of people from the working classes - in our cultural and political lives - and the impact this has on the education system and on notions of merit. 
Oliver Heath has written powerfully about how "class has been pushed outside the political system....The working class have not become incorporated within the political system - they have become more marginalized from it" (Heath, 2016, p.21). This is evidenced by the lack of working class representation in parliament, particularly in the Labour party which historically drew many of its politicians from working class backgrounds. Heath's research shows that "in 1964, Labour was not just a party that saw itself as for the working class, but was in fact substantially comprised of working class politicians, with 37 per cent of its MPs coming from manual occupational backgrounds. By 2015 this figure had fallen to just 7 per cent" (Heath, 2016). Many politicians are perceived as 'career politicians', with little experience outside 'the Westminster bubble' and higher education.

In the cultural and arts worlds, the critical absence of those from working class social origins is "a key characteristic of the British cultural and creative workforce" (Panic! Report, 2018, p.4). This is particularly true for the world of publishing but is also evident in the theatre, film and television. The report shows that "our cultural and creative workers have narrow social networks, suggesting a type of social closure within the sector" (ibid, p.3).

The current education system is clearly only part of the issue. Whilst for many it is still out of reach, alienating, or restricted - real structural and cultural barriers persist and social networks prevail. Second chance learning, therefore, as an older adult outside the 18-21 age bracket, becomes a more urgent necessity in contemporary society, despite the uplift in education and qualifications overall. Added to this, we know that some people do not fare well in primary and secondary education and that the barriers to their learning are not primarily a failure of individual effort or agency but are connected with issues of social capital and with societal and familial issues which can disrupt compulsory schooling. These might include, for instance, growing up as a looked-after child where education is patchy or inconsistent, engaging in early drug use, family break up, having an undiagnosed mental health issue or learning disability. For many people in such situations, a flexible approach to higher education was vital and often gained through further and adult education courses. Supportive resources, however, such as the Education Maintenance Allowance (EMA), introduced by the last Labour government to increase the financial viability of continuation in study for young people aged 16-19 from less well-off backgrounds, was abolished by the Coalition government in 2013. Loans were made available for further education for those aged over 24 the same year, and this was extended to 19-23 year olds (studying at Level 3 and above) in November 2015. However, taking on a loan can be especially prohibitive for part-time and mature learners. Consequently there has been a dramatic decline in this group of learners over the past 7 years. The OFFA Report of 2017 noted that this trend 'shows no sign of levelling off' and regards the decline as 'deeply worrying', seeing this issue as 
'hindering social mobility targets' (Offa, 2017, p.3). The report refers to part-time and mature learners as an 'all-too invisible' disadvantaged group.

The student experience for those who do access higher education but who do not possess the right kinds of social and cultural capital can still be profoundly alienating. Such students can become lost in the higher education system, entering a "mapless journey" as Sarah Mann has described it (Mann, 2001). This results in a dislocation with both the context of the educational experience, an uneasy relationship with the frame of discourse in which the education takes place - and particularly between student and teacher - and a feeling of being invisible and anonymous. Mann suggested that this situation is exaggerated for students from non-traditional learner backgrounds, including working class students, those from different countries and cultures, who struggle with an inexplicit and often 'hidden' cultural and academic hegemony. This can lead to a stifling of creativity or imagination and also to its distorted expression in other areas of activity, including in the areas of performance and academic conformity. The feeling of being a "stranger in a foreign land" results in a sense of alienation and powerlessness:

the student's position is akin to the colonised or the migrant from the colonised land, where the potential for alienation arises from being in a place where those in power have the potential to impose their particular ways of perceiving and understanding the world - in other words, a kind of colonising process (Mann, 2001, p.11).

As Reay has argued, the current elite representation of "the working classes as an unruly undisciplined mass has been transformed into a view of the working classes as made up of individuals who need to take more responsibility for their lives" (Reay, 2012, p.9). She argues that the prevailing view is that "class position and poverty are lifestyle choices: that anyone who wants to be, and tries hard enough, can be middle class. Changing such views is a vital precursor to a socially just educational system" (ibid). Alienation from the sources of political and economic power is built into this rhetoric. Andrew Sanchez has suggested that employment security (and its lack in precarization) is itself "an act of elite class struggle" (Sanchez, 2018, p.302) and employment (and our earning potential) is critically connected with learning and social capital.

Raymond Williams was clear that education can be a "lottery" and cannot be merely "a matter of available intelligence and available learning interest", but is, instead, an "interlock between those and the kind of learning that is at any time available and the time of life at which it comes up. This is a point that adult educationalists have of course often made. It defeats the crude, ideological attempt to write the last chapter of adult education because all the bright boys and girls have gone through the system and up the ladder"(Williams, 1983, p. 268). 


\section{Adult Education - a space for challenge and resilience}

Adult education - both current and historical - has provided an important space for communities, for part-time and mature learners, and for second chance education. It has enabled us to challenge the nature of learning and of what is deemed an appropriate subject to learn:

...in a society in which learning is unequal certain distinctive kinds of ignorance accumulate in the very heartland of learning. This heartland defines itself; it defines what learning is; it deems what is a subject and what is not (Williams, 1983, p. 259).

\section{Community}

Social and economic inclusion has been reimagined in recent times in terms of social mobility and individual "success", resulting in an emphasis on using higher education to remove young people from their communities of origin. Raymond Williams described the democratising potential of education which escaped the elite-controlled schoolhouse and university and found its expression in the family, in churches, community centres, libraries and museums. Such an approach echoed earlier working class learning experience in the reading libraries, in pubs and kitchens. It also inhered in the potential for adult education classes, particularly residential, to act as spaces for discourse and dialogue, both formal and informal, both through the lecture and around the dining table. Adult education has taken numerous forms, including university extra-curricular education, colleges offering short- and longterm residential courses, co-operative education movements and informal discussion groups.

Throughout much of the twentieth century, and particularly in the inter-war and post-Second World War period, there was a drive to develop a "common centre" (BIAE, 1924, p.26) in each area, including the most rural, which would bring together all the bodies connected with the delivery of adult education under one roof. At this time, adult education was delivered through numerous agencies, including, in rural areas, the Village Club or Institute, elementary and secondary schools and in urban areas public libraries, Adult schools and Working Men's Clubs. This was alongside evening classes offered by universities as part of their extra-mural activity and courses provided by the Workers' Educational Association. The "common centre" idea saw expression in the development of over 30 adult residential colleges, many offering short courses (a weekend to two weeks) and some - notably Ruskin College in Oxford, the oldest college established in 1899, and Fircroft College in Birmingham, established in 1909 - offering much longer courses of one to two years. Whilst the short-term colleges were technically under Local Education Authority control, they had considerable freedom and developed courses and programmes which responded to local area interest. Local Area Co-ordinators forged links with local communities at a grassroots level. As Michael Barratt Brown, former Principal of Northern College, established in 1978, described it, this was close to Raymond Williams' conception 
of a collaborative approach to adult education focused on the primacy of the 'lived experience' of the individual learner, a form of "action learning or engaged learning" ${ }^{3}$, in which groups of learners came together to share ideas and issues based on personal experience. By this means learners could have a taste of learning on a short course which might spur them on to access longer courses. Barratt Brown described it as a "nursery slope", allowing individuals who had not previously had positive experiences to gain in confidence and to learn with other like-minded people in a focused and intense environment, away from the quotidian.

Links with Trade Unions and labour organisations at colleges like Northern, also created an opportunity for working class people to gain mature scholarships. In the late 1970s courses for coalminers took place at Northern College over 10 weeks, with the miners coming through evening classes and day release courses offered by the University of Sheffield in local communities, and funded by the National Union of Miners. Northern College, dubbed 'the Ruskin of the North', and Ruskin College in particular had strong links with the trade union and labour movements: until the 1980s at least their focus was on "the promotion in a residential setting of liberal education for working class students, recruited mainly from the trade unions" (Pollins, 1984, p.63). John Prescott, former Deputy Prime Minister to Tony Blair, went as a shop steward to Ruskin College in the 1960s and has stated that his attendance at Ruskin enabled him to gain a place at Hull University later that decade. Dennis Skinner also attended Ruskin College, in 1967, after completing a course run by the NUM at the University of Sheffield. Prescott wrote, in a letter to The Guardian, "Dennis Skinner and I went to the Labour trade union's Ruskin College in Oxford, where the entry qualifications were not $\mathrm{O}$ or A-levels but your involvement in strikes" (The Guardian, Letters, $7^{\text {th }}$ July 2014). Both Prescott and Skinner are seen as genuinely representative of the working class backgrounds from which they came, in contradistinction to the 'career politicians' remarked upon in Heath's research.

\section{Political and Social Consciousness}

Research into residential adult education (Clancy and Holford, 2017) examined the four remaining residential adult education colleges: Fircroft College, Birmingham; Hillcroft College, in Surbiton, Surrey; Ruskin College in Oxford; and Northern College, in, Barnsley, South Yorkshire. The residential colleges are unique in the contemporary sphere of further and adult education in two ways - they are now the only adult education institutions which are residential in nature and they are independently constituted charities, regulated by their own trust deeds, and are no longer under local authority control. At their best, what they appear to offer is a form of education which allows for a focus on

\footnotetext{
3 I was privileged to interview Michael Barratt Brown on December 15th, 2014 shortly before he died, aged 97 (7th May 2015). In 1978 he founded Northern College at Wentworth Castle, near Barnsley, as an adult and community education residential college, and was its first principal. He retired from the College in 1983.
} 
criticality, a form of public pedagogy which is able to consider and scrutinise power differentials and fake authority, creating the space for the development of critical consciousness and political action. This could be described as education for social purpose, seeking a quantitative and then a qualitative change as its end point in real world applications. Seth Visvanathan has described this approach to education as "cognitive justice" which enables us to perceive that "diverse communities" have a stake in problem solving, based on conversation and reciprocity:

What one offers then is a democratic imagination with a non-market, non-competitive view of the world, where conversation, reciprocity, translation create knowledge not as an expert, almost zero-sum view of the world but as a collaboration of memories, legacies, heritages, a manifold heuristics of problem solving, where a citizen takes both power and knowledge into his or her own hands. These forms of knowledge, especially the ideas of complexity, represent new forms of power sharing and problem-solving that go beyond the limits of voice and resistance (Visvanathan, 2009).

At the colleges a complex understanding of the social and economic world in which we live is achieved through small group discussion work. It built on the traditions of adult education seen in the WEA and the university tutorial class movement. R.H. Tawney, the eminent adult educator, had argued that tutorial teaching should take place where students would be most comfortable, in the areas where they lived, and should be based on a small group format, of no more than thirty people, and not on formal lectures. The students agreed to read materials presented by their tutor; they agreed to undertake fortnightly essay writing and to meet once a week for a given period. The mutuality and respect emphasised by Thompson and Tawney was central. John Holford has described elements of Tawney's approach as "embryonically constructivist", in that "knowledge was created in the discussion", in a two-way exchange (Holford, 2015, p.103) which was not always comfortable but which challenged ideas of the teacher as 'guru' and fostered the notion of equality of status between the teacher and students. The residential colleges have followed this approach and, as the tutorial or seminar approach is closely associated with methods of teaching at Oxford and Cambridge, this led several of the students to refer to their own Oxbridge experience, with one person saying it was their taste of a privilege education -“a poor man's Eton" (Clancy and Holford, 2017, p.4). Critically, however, this style of teaching encourages genuine critical thinking. As Noam Chomsky expressed it, "'the core principle and requirement of a fulfilled human being is the ability to inquire and create constructively, independently, without external controls" (quoted in Open Culture, 2016). There remains a need for rebellious space and places of dissent where we can question, enquire and challenge without the dead hand of managerialism consuming democratic engagement.

\section{Ethic of service - "social purpose education"}


Because the majority of the students are from challenging backgrounds, they gain not just personal confidence through debate but also an understanding that they are not alone in their experience the creation of networks and social capital. From this learning, they return to their own communities newly equipped with an understanding of the wider societal and economic context in which they live and with a passion to work with others to support this kind of consciousness. This is what we described in the residential report as an "ethic of service" (Clancy and Holford, 2017, p. 4). This has been described as 'emotional labour', the 'emotion work' that the former students as social actors perform in the course of their daily lives when they return to their communities. This emotional labour, as Diane Reay has argued, is often part of affective and associational life -"emotional capital is generally confined within the bounds of affective relationships of family and friends and encompasses the emotional resources you hand on to those you care about" (Reay, 2004, p.60).

This 'handing on' is a source of resilience. As Sanchez identifies very poignantly in his paper, there is a complex interplay between precarity and hope. Knowing one's own history and that of the community in which one lives enables a deeper engagement with a possible future: "the degree to which persons and communities are able to construct hopeful visions of the future by drawing upon their experiences of the past is crucial to political consciousness and behaviour" (Sanchez, 2017, p. 321).

Idealized perceptions of the past structure engagements with the political life of the future. Those who have known the power of collectivised labour movements and shared action, or know their history - what he calls the "labour aristocrats" -are more resilient to the onslaught of economic injustice and inequality than those who have never known anything other than precariousness. They have a different frame of reference; they know what the "good life" looks like and how one attains it" (Sanchez, 2017, p. 302).

\section{Resources for a Journey of Hope}

"Resources for a Journey of Hope" was Raymond Williams' description of the communal means by which we seek emancipation in the last chapter of Towards 2000 (1983). Linden West echoed Williams's cry for an enduring need for resources for hope in his 2016 book, Distress in the City: Racism, Fundamentalism and a Democratic Education. West suggested that these can be found in the best traditions of adult education and informal learning - education of an "informal, life-wide kind", which allows people to challenge the "taken-for-granted without experiencing paralysing anxiety", and in the cultivation of "relationships in which individuals feel legitimate" and can restore resilience (West, 2016, p.13). 
So much of the legacy of adult education - and those aspects of it that endure (such as the residential colleges) is found in relationships, shared history and community. West refers to developments in informal education, such as Philosophy in Pubs (PiPs) - a growing movement close to the spirit of the old tutorial classes which supports grass-roots, community-based philosophy in public venues to debate important contemporary moral and philosophical issues. In a resurgence of interest in the power of adult education, these same smaller organisations continue to keep alive an alternative vision of radical, informal education which is about individual and cultural transformation. The Raymond Williams Foundation, a voluntary organisation with which I am personally involved, has espoused and promoted PiPs and utilises traditions of informal, often residential community-based discourse for democracy and social justice, in line with William's life-long social project, the creation of "an educated and participating democracy" (Williams 1961, reprinted 2001, p.389). It does this through its support Fund which was created to help adults - especially the financially and educationally disadvantaged - to attend residential education courses for lectures and discussions on big social, political, philosophical and cultural themes and through its emerging informal networks such as PiPs, pub/cafe lectures and discussion circles generally.

Social movements such as Momentum have emerged to promote new forms of political debate. In 2017, 'The World Transformed', their a fringe event held during the Labour party conference, debated issues of education - and particularly challenges to elitism in higher education - and also hosted a series of powerful workshops on the lack of working class representation in arts and culture. The Cultural Manifesto, entitled Movement for a Cultural Democracy, produced as a result of these workshops states:

"A strong democracy is an inclusive democracy. It's a society where no-one is invisible and every voice is heard. Culture, as it has been, can be the preserve of the privileged few or instead, it can be the building block that strengthens our democracy, celebrated as a basic human right, helping to create a world where all people are free to enjoy the benefits of selfexpression, access to resources and community. Our goal is to ensure that in our time it is the latter that prevails and that this transformative value, of culture for all, by all, comes to permeate all corners of our social lives and political institutions" (Movement for A Cultural Democracy, 20 December, 2017).

In November 2017, the Co-operative College hosted a conference entitled Making the Co-operative University. Its primary objective was to bring together thinkers and speakers from a range of alternative education sectors - including the Free University and Community University movements, the Social Science Centre, Lincoln - led by Professor Mike Neary - which is based on a mutual/cooperative model and leaders in Co-operative education. The conference challenged the hegemony of a marketised higher education and considered the nature of a socially just education. 
To conclude, consciousness is all and change is coming. Raymond Williams argued that "this is a social order which really does not know in what crucial respects it is ignorant, in what crucial respects it is incompletely conscious and therefore in what crucial respects this collaborative process of Adult Education is still central" (Williams, 1983, p. 264). The chapter has shown the important role adult education can play in 'left behind' communities in the grip of decline, focusing on the role of residential colleges and also non-formal, family and community learning in engaging at community level with those who have no overt 'voice' in the political system. The role of adult education in consciousness raising and in the construction of 'resources for hope' is critical, enabling us to examine how awareness of community history and labour struggles have provided continuity and resilience in times of escalating turbulence. To return to Williams' assertion that adult education has to be more than "the bottle with the message in it, bobbing on the tides and waves of history" (Williams, 1983, p. 255) we must now reclaim adult and community education as a means of contributing to the change that is necessary "in a social order which has more need of it" (ibid) than perhaps ever before.

\section{References}

BRITISH INSTITUTE OF ADULT EDUCATION (1924)The Guildhouse : a Co-Operative Centre for Adult Education. Being a Report Prepared by a Committee of Inquiry Appointed by the British Institute of Adult Education with a Foreword by Lord Eustace Percy. London: British Institute of Adult Education. 
BOURDIEU, P. (1986) The forms of capital. In J. RICHARDSON (ed.) Handbook of Theory and Research for the Sociology of Education. New York: Greenwood, pp. 241-258.

CALLAGHAN, J. (1976) Callaghan's speech (18th October 1976) has been widely reprinted. The text is available online at: http://www.educationengland.org.uk/documents/speeches/1976ruskin.html.

CLANCY, S. and HOLFORD, J. (2017) Life Changing Things Happen, Adult residential report, University of Nottingham

COOPER, V. and WHYTE, D. (2017) The Violence of Austerity, London: Pluto Press.

De VRIES and RENFROW, (2016) A Winning Personality, The effects of background on personality and earnings, Sutton Trust/University of Cambridge/University of Kent

GORARD, S. and SIDDIQUI, N. (2018) Grammar schools in England: a new analysis of social segregation and academic outcomes, British Journal of Sociology of Education, published online 26 March, 2018, DOI: 10.1080/01425692.2018.1443432

HALL, S. (1958) In the No Man's Land. In Universities and Left Review, Winter 1958, Issue 3.

HEATH, O. (2016.). Policy Alienation, Social Alienation and Working-Class Abstention in Britain, 1964-2010. British Journal of Political Science, 1-21. Published on-line 22 September 2016.

HOGGART, R. (1989) Introduction. In ORWELL, G. (1937) The Road to Wigan Pier. London: Penguin Classics pp vii-xi.

HOLFORD, J. (2016) The misuses of sustainability: Adult education, citizenship and the dead hand of neoliberalism. in International Review of Education, October 2016, Volume 62, Issue 5, pp. 541-561

HOLFORD, J.(2015) The Idea of the University in the Early Work of R.H. Tawney. In: STOILOVA, RUMIANA, PETKOVA, KRISTINA and KOLEVA, SVETLA, eds., Knowledge as a Value, Scientific Knowledge as a Vocation: Jubilee Collection in Honour of Professor Pepka Boyadjieva Sofia: Iztokzapad. 93-108

JOSEPH ROWNTREE FOUNDATION, Annual Report, MPSE 2015, November 2015.

INSTITUTE FOR VOLUNTARY ACTION RESEARCH (2018) Empowered Communities in the 2020s, IVAR Research Briefing 2 - Countries Dialogue January 2018, What does the future hold for communities in the four countries of the UK?

KOBIE, N. (2017) What is the gig economy and why is it so controversial? in Wired, 11 July 2017; Accessed 1 October 2017

MANN, S. (2001) - Alternative Perspectives on the Student Experience: alienation and engagement in Studies in Higher Education, Vol. 26, No.1

McILROY, J., Ed.; WESTWOOD, S., Ed.(1993) Border Country: Raymond Williams in Adult Education. Adult Education and Social Change, From: Adult Education and Social Change: Lectures and Reminiscences in Honour of Tony McLean, WEA Southern District, 1983, pp 9-24, London: NIACE, pp.255 -264 
McNEILIE, A. (ed.) (1988) The Essays of Virginia Woolf, Vol. III, 1919-24. London: The Hogarth Press.

OFFICE FOR FAIR ACCESS (Offa) (2017) Understanding the impact of outreach on access to higher education for adult learners from disadvantaged backgrounds: an institutional response. London: Offa. Available at: https://www.offa.org.uk/wp-content/uploads/2017/07/Final-ReportUnderstanding-the-impact-of-outreach-on-access-to-higher-education-for-disadvantaged-adultlearners-docx.pdf (accessed 31 July 2017).

OPEN CULTURE (2016) Noam Chomsky Defines What It Means to Be a Truly Educated Person in Education, Philosophy, Politics. April 28th, 2016

ORWELL, G. (1937) The Road to Wigan Pier. London: Penguin Classics

Panic! Report: Social Class, Taste and Inequalities in the Creative Industries (2018), Dr Orian Brook, Dr David O'Brien, and Dr Mark Taylor, funded by the Arts and Humanities Research Council, led by Create London and Arts Emergency

POLLINS, H. (1984) The History of Ruskin College, Oxford: Ruskin College Library Occasional Publication No. 3.

REAY, D. (2004) Gendering Bourdieu's Concepts of Capitals? Emotional Capital, Women and Social Class, The Sociological Review, Vol 52, Issue 2, pp. 57-74.

REAY, D. (2012) Think Piece - What would a socially just education system look like? July 2012, CLASS

SANCHEZ, A. (2018) 'Relative Precarity: Decline, Hope and the Politics of Work' in Industrial Labor on the Margins of Capitalism: Precarity, Class and the Neoliberal Subject. Hann, C \& Parry, JP. (eds) Berghahn pp. 297-331

SAVAGE, M. (2007) Changing Social Class Identities in Post-War Britain: Perspectives from MassObservation. in Sociological Research Online 12(3)6. <http://www.socresonline.org.uk/12/3/6.html> (Accessed 12 May 2016).

SAVAGE, M. et al (2016) Social Class in the $21^{\text {st }}$ Century. London: Pelican.

SUTTON TRUST (2017) The State of Social mobility in the UK, Boston Consulting Group, Sutton Trust, July 2017

SUTTON TRUST (2010), Responding to the new landscape for university access, Sutton Trust

SUTTON TRUST (2016) Oxbridge admissions, Sutton Trust

THE COMPLETE UNIVERSITY GUIDE https://www.thecompleteuniversityguide.co.uk/leaguetables/rankings

THE GUARDIAN, Letters, $7^{\text {th }}$ July 2014

THE TIMES, March 28 2018, Rosemary Bennett, Oxford University is bottom of the class for accepting poor students 
VISVANATHAN, S. (2009) "The search for cognitive justice", http://www.indiaseminar.com/2009/597/597_shiv_visvanathan.htm. Retrieved 3 October 2017.

WILLIAMS, R. (1961/2011), The Long Revolution. Swansea: Parthian Books.

WEST, L. (2016) Distress in the City - Racism, Fundamentalism and a Democratic Education. London: U.C.L., IOE Press. 